\title{
Biochemical Analysis of an Indigenous Fish Barilius bendelisis
}

\author{
Gobinda Chandra De1, Debashis Das² and Abhisek Saha ${ }^{3 *}$ \\ ${ }^{1} 1$ Department of Chemistry, Associate Professor, Cooch Behar Panchanan \\ Barma University, Cooch Behar, West Bengal, India \\ 2Department of Zoology, Associate Professor, Tufanganj \\ Mahavidyalaya, Cooch Behar, West Bengal, India \\ 3*Department of Chemistry, Assistant Professor, Tufanganj \\ Mahavidyalaya, Cooch Behar, West Bengal, India
}

\section{ABSTRACT}

Transboundary river Torsa, Raidak-1, Jaldhaka( Mansai) flowing through Cooch Behar district of West Bengal, India. A proximate study on the biochemical contents of a commonly consumed and available popular freshwater small indigenous fish (SIS) of these rivers was done to calculate their nutritive value. Most important nutrient composition of Barilius bendelisis (commonly known as Boroli fish) like protein, fat, moisture, ash calculated by standard 'AOAC' procedures (AOAC, 2005). The unrefined protein content shifted somewhere in the range of 16.86\% and 16.72\% with the most extreme protein content found in fish collected in Jaldhaka (Mansai)and least in the Raidak-1 river. So also, the fat content was assorted from $6.54 \%$ to $6.45 \%$. Moisture content demonstrates a variety from $73.38 \%$ to $72.99 \%$ though, the ash content changed from $3.42 \%$ to $3.34 \%$. The present work clearly shows that 'SIS' is the economical source of quality protein which can provide nutritional security, source of revenue safety and can solve the protein need of the locality. Enhancement of the production by aquaculture and consumption of small fishes encouraged for a better way to meet protein hunger of this region.

KEY WORDS: SMALL INDIGENOUS SPECIES (SIS), PROXIMATE COMPOSITION, PROTEIN HUNGER, REVENUE SAFETY, NUTRITIVE VALUE.

\section{INTRODUCTION}

The current picture of worldwide socioeconomics reveals to us that the total populace is rising and will keep on expanding. As indicated by insights, the total populace is approximately seven billion at present and by 2050 it will reach nine billion 1 . A report estimated the urgent

\section{ARTICLE INFORMATION}

Received 26th Oct 2020 Accepted after revision 11th Dec 2020 Print ISSN: 0974-6455 Online ISSN: 2321-4007 CODEN: BBRCBA

Thomson Reuters ISI Web of Science Clarivate Analytics USA and Crossref Indexed Journal

\section{Clarivate
Analytics}

NAAS Journal Score 2020 (4.31)

A Society of Science and Nature Publication,

Bhopal India 2020. All rights reserved.

Online Contents Available at: http//www.bbrc.in/

Doi: http://dx.doi.org/10.21786/bbrc/13.15/38 need to construct mass food production by over $40 \%$ by 2030 and above $70 \%$ by 2050 . The small indigenous fish species (SIS) can take for granted a basic work in the avoidance of micro-nutrient inadequacies and associated diseases 2-5. All-inclusive, it is usual that animal protein consumption will be twofold in the principal half of this century. Fish as the least expensive source of efficiently digestible animal protein demonstrates a noteworthy offer in the worldwide nourishment bin and undoubtedly, the strongest progress is normal in the utilization of fish which meet the protein hunger, employment and nutritional security in the coming days 6 .

India is occupied by various freshwater fish species and around 2,246 indigenous finfish species have been recorded available till now. Around 765 species are accounted for to have from freshwater and out of those

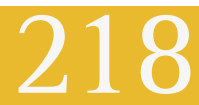


450 species are considered as small indigenous fishes (SIS). These little fishes are an important source of micronutrients, inexpensive sources of high-quality animal proteins which involve a noteworthy piece of captured and cultured inland fisheries and contribute highly to the nutritional as well as the livelihood security of the rural society 7. 'SIS' are those species which can develop most extreme to a length of $25-30 \mathrm{~cm}$ in the development or grown-up phase of their lifecycle 8. Significant food values of fish are given in the following figure( Figure.1). West Bengal has importance for per capita fish consumers amongst the states of India with nearly $96 \%$ of the population being fish eater. Small fishes are nutrient-rich but normally overlooked in developing countries 9. On the off chance that overall population wellbeing is concerned, it is necessary to know the nutritive value of the little indigenous fishes from West Bengal to understand their nutritive value regarding food, nutritional protection, and for the betterment of economic condition.

Figure 1: Important food value of fish.

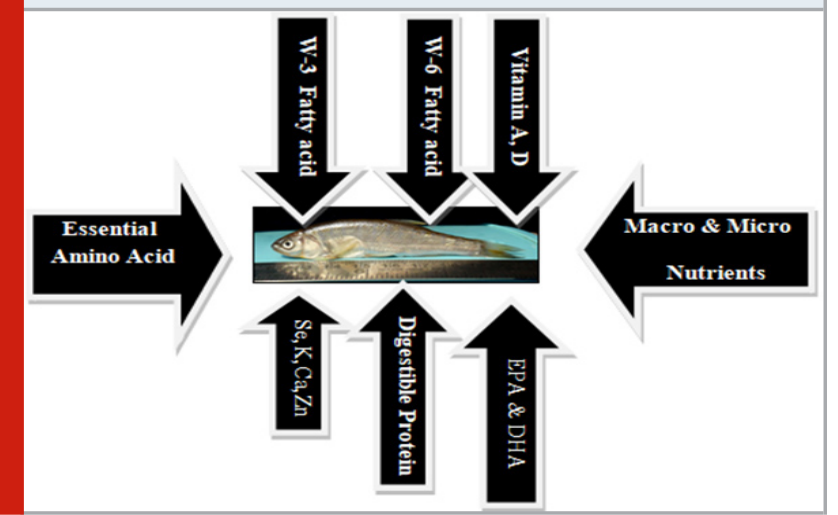

Information on the biochemical composition is essential for preparing and safeguarding fish and fishery items. Data on the biochemical constituents will make it easy for a processing technologist to define the ideal preparing and capacity conditions with the goal that the quality protected to the highest degree as fish is a well transitory product and weakening in quality is because of the progressions occurring in the proximate composition. Consciousness has already reached among the people about healthy food and fish is finding more reliable because of its sole nutritional qualities. A suitable understanding of the biochemical constituents of fish has become a primary essential for nutritionists and dieticians.

Lack of satisfactory data on biochemical composition of fish from rivers of the northern region of West Bengal, India hence the consumer and fishery workers are left with insufficient information's on the significance of few fish species in their daily diets 10 . The present investigation has a justification to provide a piece of important information on the biochemical composition of some species marketed in the locality. Considering the importance of the small indigenous fishes and Very few published information is available on the biochemical composition of the small indigenous fish species of West Bengal, this study targeted to determine the biochemical composition of popular indigenous small fish named Barilius bendelisis( locally popular boroli fish) found in Torsa, Raidak-1, Jaldhaka(Mansai) river of Cooch Behar District of West Bengal, India.

\section{MATERIAL AND METHODS}

Sampling Site: Fresh fish sample of Barilius bendelisis collected from fishermen landing at the bank of the Torsa, Raidak-1, Jaldhaka river of Cooch Behar district which is situated in the northern part of West Bengal. It is very important to check the health status of aquatic life, from the perspective of knowledge about biodiversity, because these rivers traverse a vast territory through different countries as well as to document comprehensive nutrient profiles with a specific focus on important small indigenous species (SIS) availability in Cooch Behar for pre-monsoon, monsoon and the post-monsoon period during the period of March 2019 to November 2019. Global positioning system reading of nine sampling sites(Fig.2) are Torsa river (ST1-26 $21^{\prime} 27^{\prime \prime} \mathrm{N}, 8^{\circ} 22^{\prime} 42^{\prime \prime} \mathrm{E}$, $158 \mathrm{ft}$ ), Torsa river (ST2-26 $17^{\prime} 13^{\prime \prime} \mathrm{N}, 8^{\circ} 27^{\prime} 33^{\prime \prime} \mathrm{E}, 122 \mathrm{ft}$ ), Torsa river (ST3-26 $15^{\circ} 5^{\prime \prime} \mathrm{N}, 89^{\circ} 36^{\prime} 37^{\prime}$ ”E, $109 \mathrm{ft}$ ),Raidak-1 river(SR1-26 21'07'N, 89 40'29'"E, 122ft), Raidak-1 river(SR2-26 18'39”'N , 8940'14”'E,118ft), Raidak-1 river (SR3-26 $13^{\prime} 09^{\prime \prime} \mathrm{N}, 8^{\circ} 41^{\prime} 37^{\prime \prime} \mathrm{E}, 104 \mathrm{ft}$ ), Jaldhaka(Mansai river) ( SJ1-26 $21^{\prime} 35^{\prime \prime} \mathrm{N}, 89^{\circ} 13^{\prime} 31^{\prime \prime} \mathrm{E}, 146 \mathrm{ft}$ ), Jaldhaka( Mansai river) ( SJ2-26 $19^{\prime} 10^{\prime \prime} \mathrm{N}$, 89 $9^{\circ} 14^{\prime} 23^{\prime \prime} \mathrm{E}, 157 \mathrm{ft}$ ),

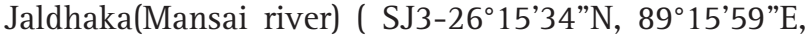
$137 \mathrm{ft})$. The fish samples collected from fishermen from different spots (were transported in an insulated icebox with a proper identification mark to the laboratory.

Figure 2: Fish collection spots of three rivers in Google Earth.

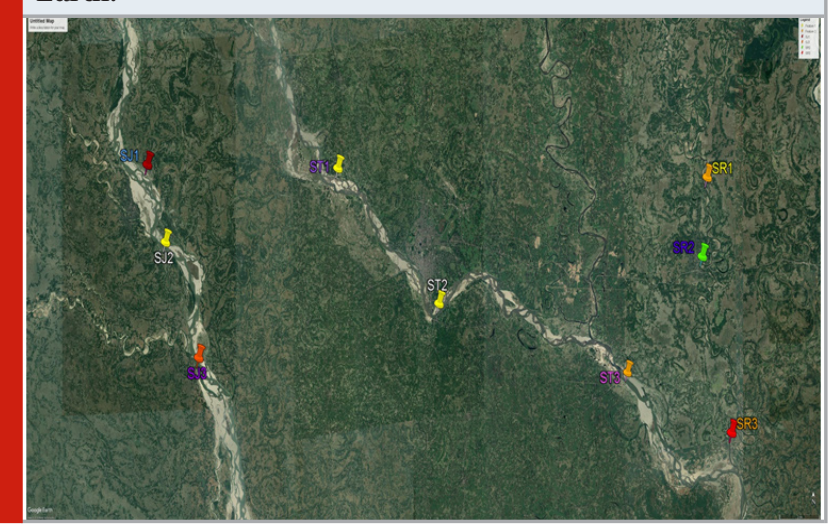

Laboratory Study of Samples: In the laboratory, the fish samples identified using the taxonomy keys, the color, color patterns, spots, and their picture taken by a DSLR camera. The fishes were identified by studying their morphometric and meristic characters and by taking into consideration the literature of Talwar and Jhingran, 1991 and Jayaram, 1999 and 2006 11-13. The notable sample was then set apart in triplicates as Standard length, absolute length, and weight of fish sample recorded. The proximate composition of Barilius 
bendelisis was analyzed by standard 'AOAC' procedures (AOAC, 2005) 14.

Total Moisture Determination: Triplicates of the preweigh samples were put into Petri dishes dried in an air-dry spell oven. The drying was done at 100-1050 C until a steady weight was accomplished. It was then taken out from the Oven, put in a desiccator, allowed to cool, and weighed. Moisture content was calculated from the difference in weight of the sample.

Table 1. Protein, Fat (\% wet weight basis) of Barilius bendelisis (SIS) of Torsa river of Cooch Behar district of West Bengal, India.

\begin{tabular}{|c|c|c|c|c|c|c|}
\hline River & Site & Period & Moisture $(\mathrm{g} / 100 \mathrm{~g})$ & Crude Fat $(\mathrm{g} / 100 \mathrm{~g})$ & Crude Protein $(\mathrm{g} / 100 \mathrm{~g})$ & $\operatorname{Ash}(g / 100 g)$ \\
\hline \multirow[t]{3}{*}{ Torsa } & ST1 & Pre monsoon & 72.77 & 6.38 & 16.66 & 3.42 \\
\hline & ST2 & Pre monsoon & 72.2 & 6.37 & 16.54 & 3.37 \\
\hline & ST3 & Pre monsoon & 72.38 & 6.4 & 16.88 & 3.46 \\
\hline Mean Value(Mean \pm 2 sd) & & & $72.45 \pm 0.33$ & $6.38 \pm 0.0173$ & $16.69 \pm 0.19$ & $3.42 \pm 0.05$ \\
\hline \multirow[t]{3}{*}{ Torsa } & ST1 & Monsoon & 72.45 & 6.31 & 16.6 & 3.41 \\
\hline & ST2 & Monsoon & 72.39 & 6.3 & 16.52 & 3.33 \\
\hline & ST3 & Monsoon & 72.11 & 6.33 & 16.65 & 3.4 \\
\hline Mean Value(Mean \pm 2 sd) & & & $72.32 \pm 0.20$ & $6.31 \pm 0.02$ & $16.59 \pm 0.07$ & $3.38 \pm 0.05$ \\
\hline \multirow[t]{5}{*}{ Torsa } & ST1 & Post monsoon & 73.58 & 6.55 & 16.98 & 3.48 \\
\hline & ST2 & Post monsoon & 74.69 & 6.45 & 16.58 & 3.42 \\
\hline & ST3 & Post monsoon & 74.71 & 6.98 & 17.28 & 3.49 \\
\hline & & $\min$ & 73.58 & 6.45 & 16.58 & 3.42 \\
\hline & & $\max$ & 74.71 & 6.98 & 17.28 & 3.49 \\
\hline \multirow[t]{2}{*}{ Mean Value(Mean \pm 2 sd) } & & & $74.33 \pm 0.73$ & $6.66 \pm 0.32$ & $16.95 \pm 0.39$ & $3.46 \pm 0.04$ \\
\hline & & \multicolumn{3}{|c|}{ Approx. $95 \%$ of the data lies between \pm 2 SD } & & \\
\hline
\end{tabular}

Table 2. Protein, Fat (\% wet weight basis) of Barilius bendelisis (SIS) of Raidak-1river of Cooch Behar district of West Bengal, India.

\begin{tabular}{|c|c|c|c|c|c|c|}
\hline River & Site & Period & Moisture $(\mathrm{g} / 100 \mathrm{~g})$ & Crude Fat(g/100g) & Crude Protein $(\mathrm{g} / 100 \mathrm{~g})$ & Ash $(g / 100 \mathrm{~g})$ \\
\hline \multirow[t]{3}{*}{ Raidak-1 } & SR1 & Pre monsoon & 72.19 & 6.48 & 16.76 & 3.32 \\
\hline & SR2 & Pre monsoon & 72.15 & 6.5 & 16.68 & 3.35 \\
\hline & SR3 & Pre monsoon & 72.4 & 6.52 & 16.88 & 3.38 \\
\hline Mean Value(Mean \pm 2 sd) & & & $72.25 \pm 0.15$ & $6.5 \pm 0.02$ & $16.77 \pm 0.12$ & $3.35 \pm 0.03$ \\
\hline \multirow[t]{3}{*}{ Raidak-1 } & SR1 & Monsoon & 72.38 & 6.34 & 16.6 & 3.4 \\
\hline & SR2 & Monsoon & 72.22 & 6.33 & 16.55 & 3.33 \\
\hline & SR3 & Monsoon & 72.16 & 6.39 & 16.67 & 3.47 \\
\hline Mean Value(Mean \pm 2 sd) & & & $72.25 \pm 0.13$ & $6.35 \pm 0.03$ & $16.61 \pm 0.06$ & $3.4 \pm 0.07$ \\
\hline \multirow[t]{3}{*}{ Raidak-1 } & SR1 & Post monsoon & 74.48 & 6.52 & 16.77 & 3.45 \\
\hline & SR2 & Post monsoon & 74.49 & 6.5 & 16.62 & 3.4 \\
\hline & SR3 & Post monsoon & 74.4 & 6.77 & 16.98 & 3.48 \\
\hline \multirow[t]{2}{*}{ Mean Value(Mean \pm 2 sd) } & & & $74.46 \pm 0.05$ & $6.59 \pm 0.17$ & $16.79 \pm 0.20$ & $3.44 \pm 0.04$ \\
\hline & & \multicolumn{3}{|c|}{ Approx. $95 \%$ of the data lies between $\pm 2 \mathrm{SD}$} & & \\
\hline
\end{tabular}

Table 3. Protein, Fat (\% wet weight basis) of Barilius bendelisis (SIS) of Jaldhaka(Mansai) river of Cooch Behar district of West Bengal, India.

\begin{tabular}{|c|c|c|c|c|c|c|}
\hline River & Site & Period & Moisture $(\mathrm{g} / 100 \mathrm{~g})$ & Crude Fat $(\mathrm{g} / 100 \mathrm{~g})$ & Crude Protein(g/100g) & $\operatorname{Ash}(\mathrm{g} / 100 \mathrm{~g})$ \\
\hline \multirow[t]{3}{*}{ Jaldhaka } & SJ1 & Pre monsoon & 73.98 & 6.59 & 17.01 & 3.4 \\
\hline & $\mathrm{SJ} 2$ & Pre monsoon & 73.13 & 6.31 & 16.98 & 3.33 \\
\hline & SJ3 & Pre monsoon & 74.14 & 6.66 & 17.08 & 3.44 \\
\hline \multicolumn{2}{|c|}{ Mean Value(Mean \pm 2 sd) } & & $73.75 \pm 0.6$ & $6.52 \pm 0.21$ & $17.02 \pm 0.05$ & $3.39 \pm 0.06$ \\
\hline \multirow[t]{3}{*}{ Jaldhaka } & SJ1 & Monsoon & 72.3 & 6.42 & 16.59 & 3.32 \\
\hline & $\mathrm{SJ} 2$ & Monsoon & 72.28 & 6.4 & 16.22 & 3.3 \\
\hline & SJ3 & Monsoon & 72.33 & 6.49 & 16.7 & 3.38 \\
\hline \multicolumn{2}{|c|}{ Mean Value(Mean \pm 2 sd) } & & $72.30 \pm 0.02$ & $6.43 \pm 0.05$ & $16.50 \pm 0.28$ & $3.33 \pm 0.04$ \\
\hline \multirow[t]{3}{*}{ Jaldhaka } & SJ1 & Post monsoon & 74.44 & 6.68 & 17.1 & 3.31 \\
\hline & $\mathrm{SJ} 2$ & Post monsoon & 73.26 & 6.52 & 16.98 & 3.3 \\
\hline & SJ3 & Post monsoon & 74.56 & 6.78 & 17.12 & 3.35 \\
\hline \multicolumn{2}{|c|}{ Mean Value(Mean \pm 2 sd) } & & \begin{tabular}{|l|l|}
$74.09 \pm 0.81$ \\
\end{tabular} & $6.66 \pm 0.15$ & $17.07 \pm 0.08$ & $3.32 \pm 0.02$ \\
\hline & & & & \multicolumn{3}{|c|}{ Approx. $95 \%$ of the data lies between \pm 2 SD } \\
\hline
\end{tabular}

Total Crude Protein Determination: To calculate the protein content of the sample, a Micro-Kjeldahl Nesslerization procedure was applied. $2 \mathrm{~g}$ of the sample was taken into three different Kjeldahl digestion flasks containing $20 \mathrm{ml}$ of Concentrated $\mathrm{H}_{2} \mathrm{SO}_{4}$ and a spatula of Kjeldahl catalyst. The flask was gently heated at first till frothing stops then boiling very fast till mixture was colorless. In the wake of cooling the mixture, 100 $\mathrm{ml}$ water was included. From the diluted part of this solution, $1 \mathrm{ml}$ is taken and with this $4 \mathrm{ml}$, Nessler's 
reagent was added. The absorbance of this mixture read spectrophotometrically at 490nm against a blank. 0.01g per $100 \mathrm{ml}$ of water considered as the sample. Protein content was determined by multiplying it by 6.25 .

Total Crude Fat Determination: In a conical flask, 14 $\mathrm{g}$ finely homogenized flesh and bone were taken and chloroform and methanol mixture (1:2) was added to it. The blend was centrifuged for five minutes. The supernatant was decanted repeatedly by using a filter paper and to end with, $0.8 \mathrm{ml}$ water was added with the residue. To the supernatant, Chloroform was added to make a ratio of 1:1. separating funnel was used to separate oil. The solvent was evaporated at 400C and weighed taken. By using Soxhlet apparatus petroleum ether (boiling range $40-60^{\circ} \mathrm{C}$ ) crude fat was determined.

Total Ash Determination: In different porcelain dishes, $1 \mathrm{~g}$ of the triplicate sample was weighed. A $5 \mathrm{ml}$ solution of aluminum nitrate and calcium nitrate was added to it. The mixture was dried at $100^{\circ} \mathrm{C}$. When the sample was charred, and then places it in a muffled furnace at $450^{\circ} \mathrm{C}$ overnight. After cooling in a desiccator, reweighed to calculate the ash content.

Statistical Analysis: The statistical investigation was finished utilizing MS-Excell Programming.

Ethical issues: The examination was as per the Declaration of Helsinki and guidelines on good clinical practice locally accessible. It was likewise endorsed by the institutional ethics board and morals committee 15 .

\section{RESULTS}

The proximate composition of Barilius bendelisis are shown in Table 1, Table 2, and Table 3 for Torsa, Raidak-1, Mansai( Jaldhaka) river for three periods at three sites of each river respectively. The outcomes from the present examination uncovered that moisture, protein, fat, and ash showed variations in three seasons at three sites for the collected small fish species.

Total Protein Content: The muscle protein content went somewhere in the range of $16.88 \%$ and $16.54 \%$ for the fish collected in the pre-monsoon period, $16.65 \%$ and $16.52 \%$ in the monsoon period, $17.28 \%$ and $16.58 \%$ in the post-monsoon period from the fish collected from the Torsa River (Table.1). The crude protein content showed $16.88 \%$ and $16.68 \%$ for the fish collected in the premonsoon period, $16.67 \%$ and $16.55 \%$ in the monsoon period, $16.98 \%$ and $16.62 \%$ in the post-monsoon period from the fish collected from Raidak-1 river (Table.2). Whereas crude protein content showed the range $17.08 \%$ and $16.98 \%$ for the fish collected in the pre-monsoon period, $16.70 \%$ and $16.22 \%$ in the monsoon period, $17.12 \%$ and $16.98 \%$ in the post-monsoon period from the fish collected from Jaldhaka( Mansai) river (Table.3).

It was found from our study that crude protein content showed maximum value for the fish collected from the sites at ST3, SR3, SJ3 and minimum value from the fish collected from the sites ST2, SR2, SJ2 (Figue.3 to Figure.10). Another remarkable feature was that the crude protein content of the fish is highest in Jaldhaka(Mansai) river and lowest in the Torsa river in the pre-monsoon period(Figure. 12). In the monsoon period, the crude protein content is highest in the Torsa river whereas lowest in Jaldaha(Mansai river) (Figure.13).

Figure 3: Variation of protein content (\%) of the species collected from Torsa river in the pre-monsoon period.

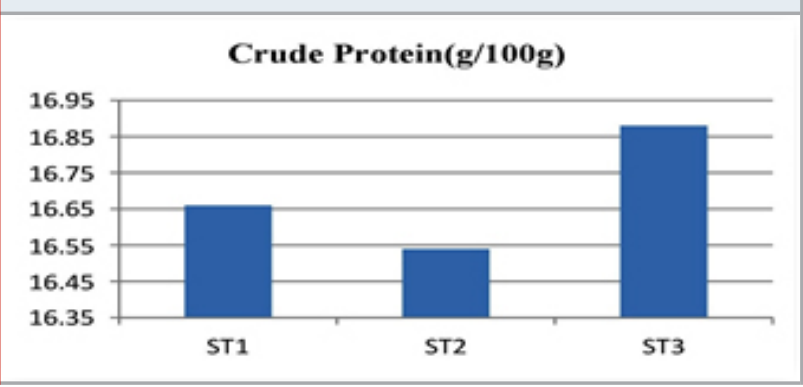

Figure 4: Variation of protein content $(\%)$ of the species collected from Torsa river in the monsoon period.

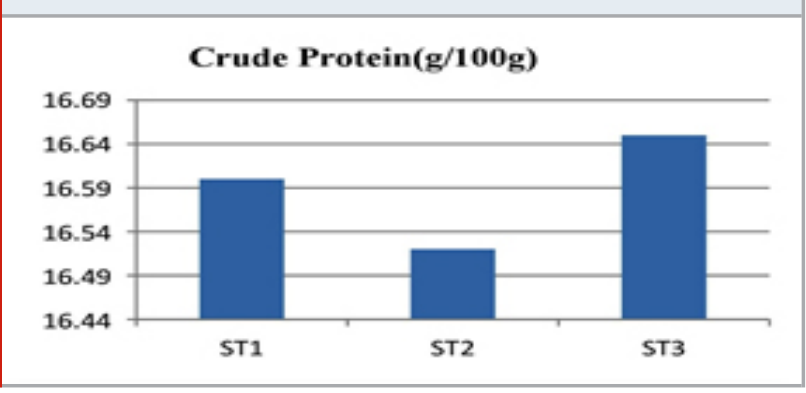

Figure 5: Variation of protein content (\%) of the species collected from Torsa river in the post-monsoon period.

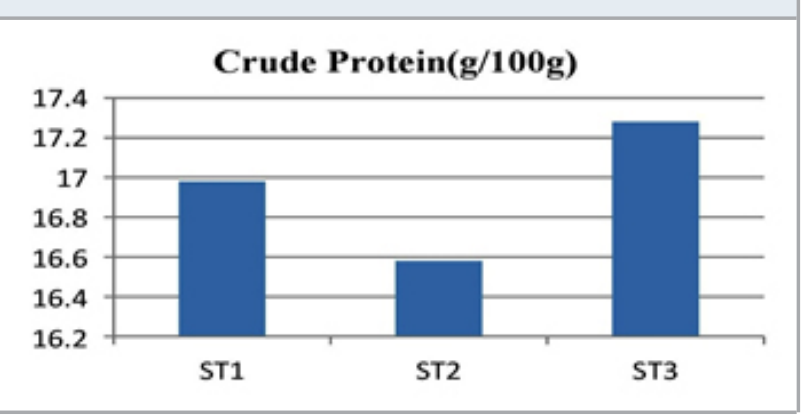

In the studied period, the fish crude protein content is highest in Jaldhaka(Mansai) and lowest in the Raidak-1 river during the post-monsoon period (Figure.14). It was also evident from our study that crude protein content of the studied fish was higher from the fish collected from the Jaldhaka (Mansai) river and lowest in the fish collected from Raidak-1 river when we are taking an average of three seasons i.e. pre-monsoon, monsoon, and post-monsoon period (Figure.15). 
Figure 6: Variation of protein content(\%) of the Species collected from Jaldhaka(Mansai) river in the pre-monsoon period.

\section{Crude Protein(g/100g)}

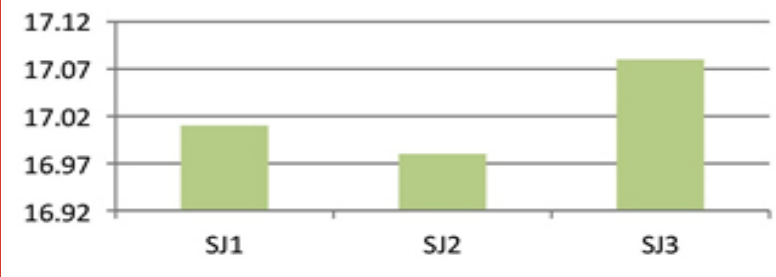

Figure 7: Variation of protein content(\%) of the Species collected from Jaldhaka(Mansai) river in the monsoon period.

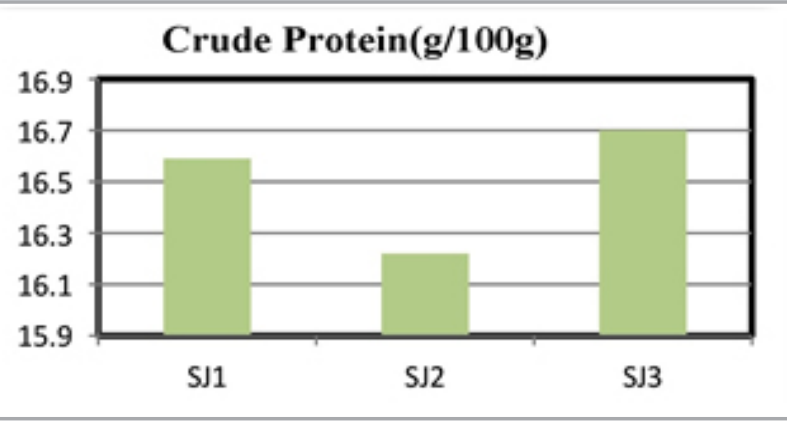

Figure 8: Variation of protein content (\%) of the species collected from Mansai(Jaldhaka) in the post-monsoon period.

\section{Crude Protein(g/100g)}

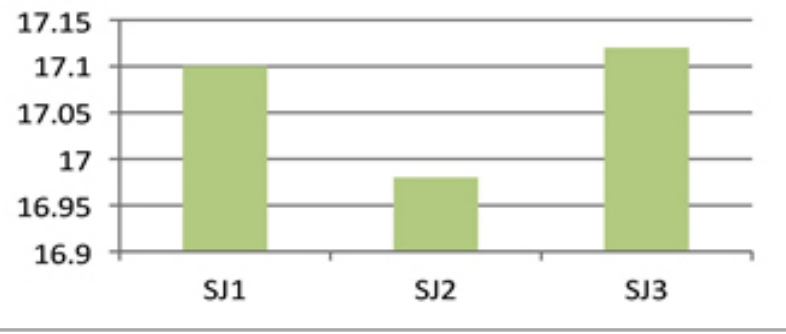

Figure 9: Variation of protein content (\%) of the collected from Raidak-1 river in the pre-monsoon period.

\section{Crude Protein(g/100g)}

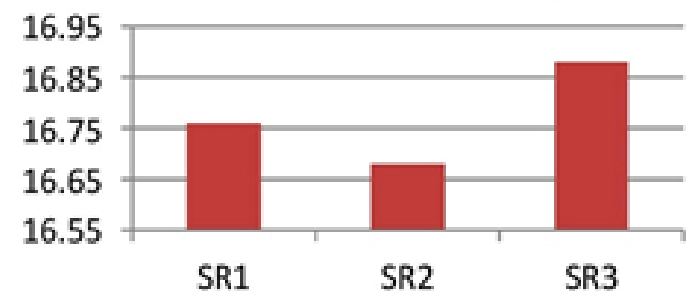

Figure 10: Variation of protein content ( $\%)$ of the collected from Raidak-1 river in the pre-monsoon period.

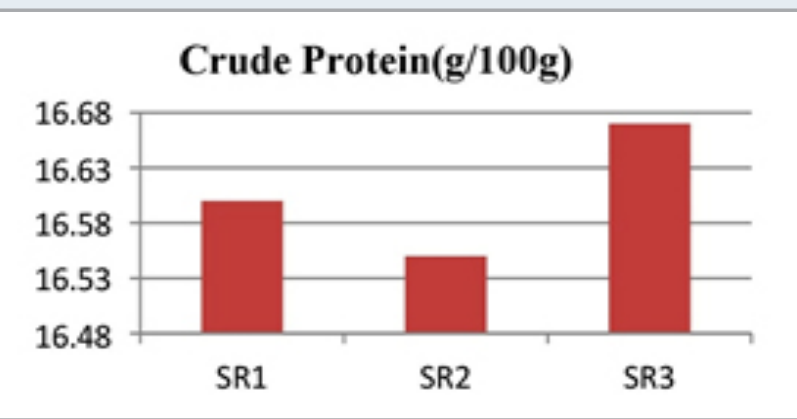

Figure 11: Variation of protein content (\%) of the species collected from Torsa river in the post-monsoon period.

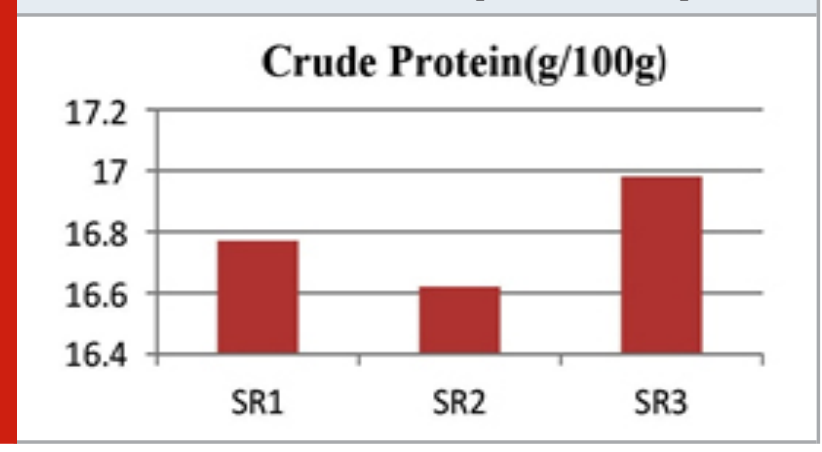

Figure 12: Variation of protein content (\%) of the species collected from three rivers in the pre-monsoon period.

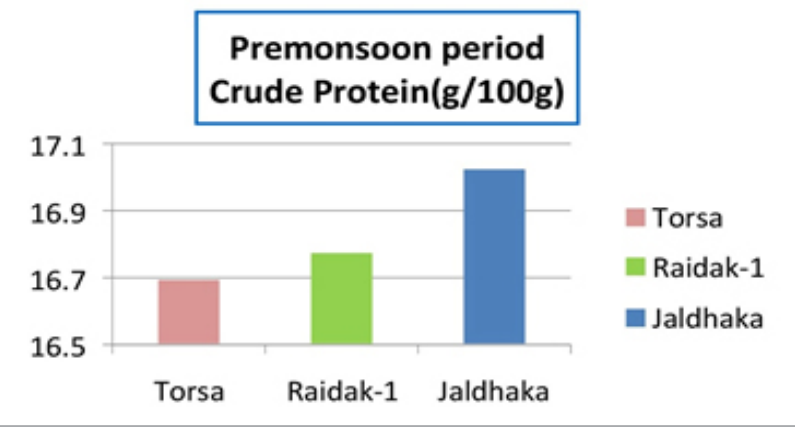

Figure 13: Variation of protein content (\%) of the species collected from three rivers in the monsoon period.

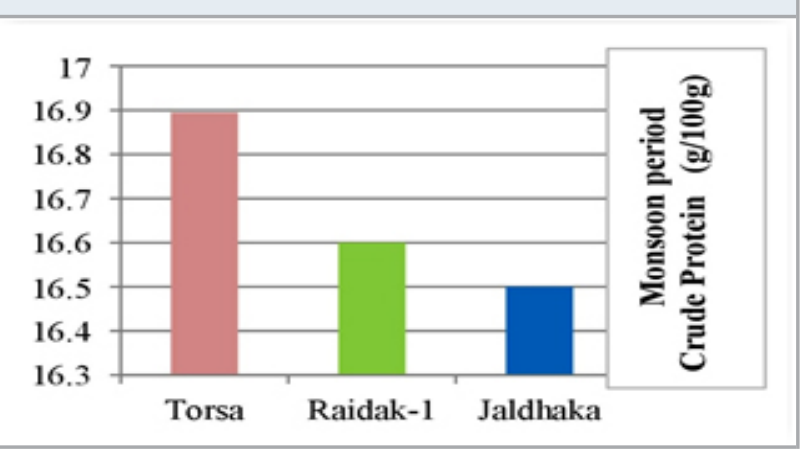


Figure 14: Variation of protein content (\%) of the species collected from three rivers in the post-monsoon period.

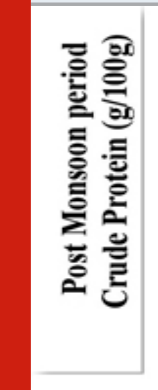

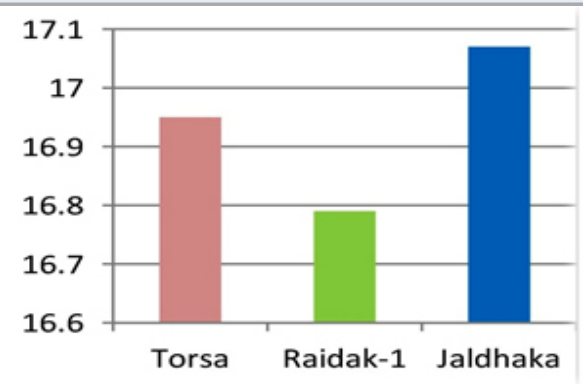

Figure 15: Variation of protein content (\%) of the species collected from three rivers in three seasons.

\section{Crude Protein(g/100 g)}

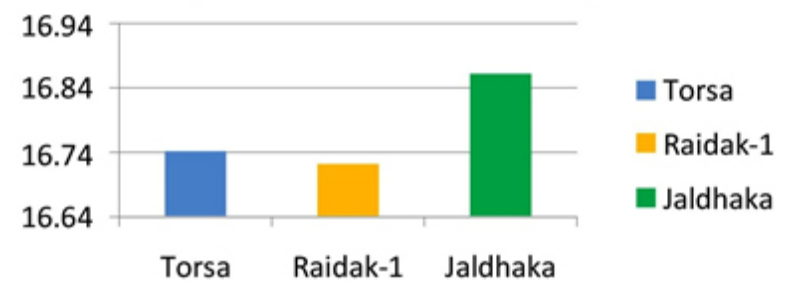

Total Crude Fat Content: The crude fat content went somewhere in the range of $640 \%$ and $6.37 \%$ for the fish collected in the pre-monsoon period, $6.33 \%$ and $6.30 \%$ in the monsoon period, $6.98 \%$ and $6.45 \%$ in the postmonsoon period from the fish collected from the Torsa River (Table.1). The crude fat content showed 6.52\% and $6.48 \%$ for the fish collected in the pre-monsoon period, 6.39\% and 6.33\% in the monsoon period, 6.77\% and $6.50 \%$ in the post-monsoon period from the fish collected from Raidak-1 river (Table.2).

Whereas crude fat content showed the range 6.66\% and $6.31 \%$ for the fish collected in the pre-monsoon period, $6.49 \%$ and $6.40 \%$ in the monsoon period, $6.78 \%$ and $6.52 \%$ in the post-monsoon period from the fish collected from Jaldhaka( Mansai) river (Table.3). It was found from our study that crude fat content showed maximum value for the fish collected from the Raidak-1 river and minimum value from the fish collected from the Torsa river in the pre-monsoon period (Figure.16) whereas crude fat content showed maximum value for the fish collected from the Jaldhaka(Mansai) river and minimum value from the fish collected from the Torsa river in the monsoon period (Figure.17). Crude fat content showed maximum value for the fish collected from the Raidak-1 river and minimum value from the fish collected from the Torsa river in the post-monsoon period (Figure.18).

It was also evident from our study that the crude fat content of the studied fish was higher from the fish collected from the Jaldhaka (Mansai) river and lowest in the fish collected from the Torsa river when we are taking an average of three seasons i.e. pre-monsoon, monsoon and post-monsoon period (Figure.19).

Figure 16: Variation of crude fat content (\%) of the species collected from three rivers in the pre-monsoon period.

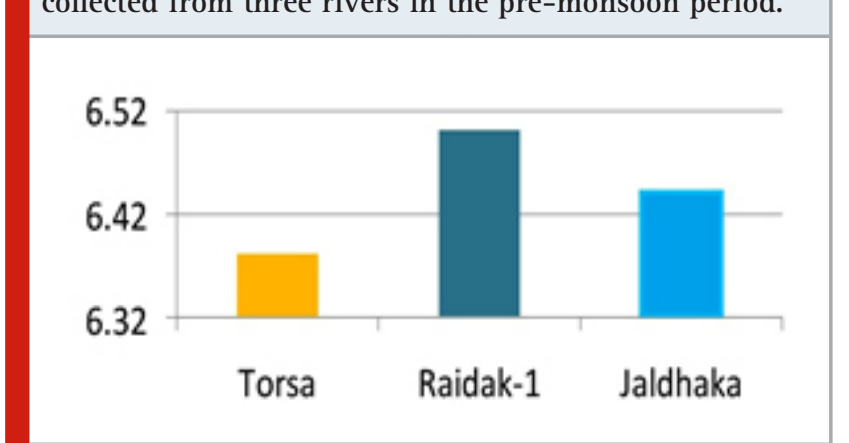

Figure 17: Variation of crude fat content (\%) of the species collected from three rivers in the monsoon period.

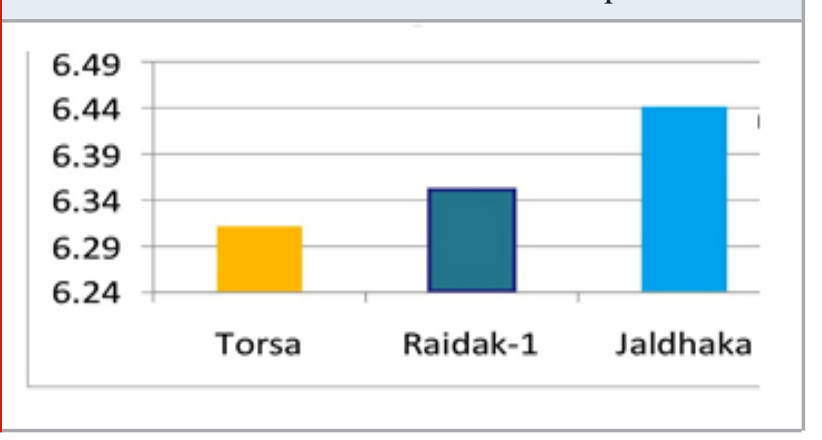

Figure 18: Variation of protein content (\%) of the species collected from three rivers in the post monsoon period.

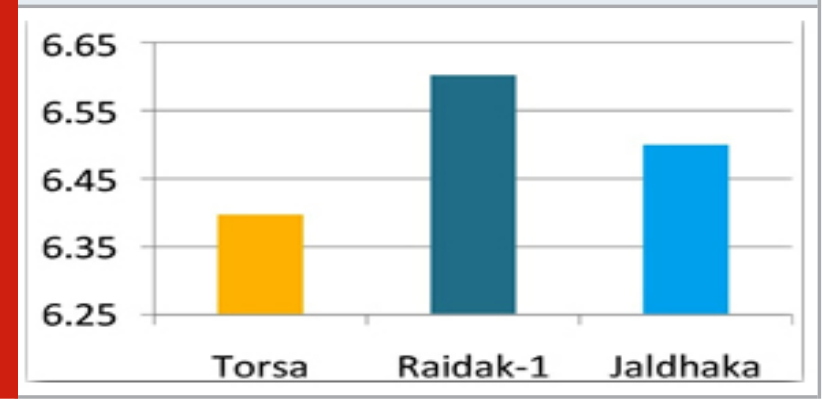

Figure 19: Variation of crude fat content (\%) of the species collected from three rivers in three seasons.

\section{Crude Fat(g/100g)}

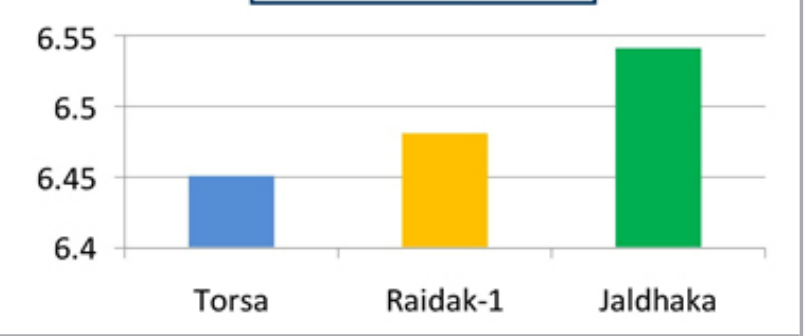


Total Moisture Content: The moisture i.e. water content went somewhere in the range of $72.77 \%$ and72.20 \% for the fish collected in the pre-monsoon period,72.45 \% and $72.11 \%$ in the monsoon period, 74.71\% and $73.58 \%$ in the post-monsoon period from the fish collected from Torsa river (Table.1). The water content showed 72.40\% and72.15\% for the fish collected in the pre-monsoon period, and $72.38 \%$ and $72.16 \%$ in the monsoon period, and $74.49 \%$ and $74.40 \%$ in the post-monsoon period from the fish collected from Raidak-1 river (Table.2). Whereas moisture content showed the range $74.14 \%$ and $73.13 \%$ for the fish collected in the pre-monsoon period, and $72.33 \%$ and $72.28 \%$ in the monsoon period,74.56 \% and $73.26 \% \%$ in the post-monsoon period from the fish collected from Jaldhaka( Mansai) river (Table.3).

Total Ash Content: The ash content went somewhere in the range of $3.46 \%$ and $3.37 \%$ for the fish collected in the pre-monsoon period, $3.41 \%$ and $3.33 \%$ in the monsoon period, $3.49 \%$ and $3.42 \%$ in the post-monsoon period from the fish collected from the Torsa River (Table.1). The ash content showed 3.38\% and3.32\% for the fish collected in the pre-monsoon period, and $3.47 \%$ and $3.33 \%$ in the monsoon period, and $3.48 \%$ and $3.40 \%$ in the post-monsoon period from the fish collected from Raidak-1 river (Table.2). Whereas ash content showed the range $3.44 \%$ and $3.33 \%$ for the fish collected in the pre-monsoon period, and3.38 \% and3.30 \% in the monsoon period, $3.35 \%$ and $3.30 \%$ in the post-monsoon period from the fish collected from Jaldhaka( Mansai) river (Table.3).

\section{DISCUSSION}

The biochemical analysis of principle constituents namely; protein, fat, carbohydrate, ash, and water varies greatly for different species and in between the same species depending on diverse factors like age, sex, environment condition, and also seasonal variation 16,17. The biochemical constituents of fishes are closely related to feeding intake, migratory factor, and sexual changes in the relationship with spawning 18 . Fish growth is subjective by several factors such as food, space, temperature, the salinity of water, seasonal change, and different human activity. Fishes are poikilothermic and live permanently immersed in water so directly affected by alteration in their ambient medium 19 .

The results obtained regarding the proximate analysis of Barilius bendelisis showed few similarities with the assessment made by other researchers in this field 20,21,22. However, differences with other researchers may be accredited to different physiological conditions of different locations, period, age of fish including length during the time of sampling in the study period. Generally, proteins are found in fish mussel which includes varieties like a. Sarcoplasmic proteins such as myogen, globulin, and so forth. b. myofibrillar proteins which include actin, myosin, actomyosin, tropomyosin, troponins, and so forth c.Stroma proteins include connective tissues of the muscle. Protein like collagen, present in skin, the air bladder is another type of protein which is present in fish 23. Fish comprises a remarkable source of protein in our eating routine 24 . A broad span of proteins happens which are twenty number of amino acids connected in an alternating plan.

Half of the units are named fundamental as they can't be prepared synthetically and like so fish is important in keeping up the right dietary parity 25. .The protein content of fish mussel showed a range of $16.86 \%$ and $16.72 \%$ in our present study. Protein is important for the upkeep of good wellbeing 26. In fish, the muscle protein content, for the most part, stays higher than every single other supplement 26. Fish food organisms in the water may alter the protein content of the mussel. Individual agro-climatic conditions in different topographical regions have a more important impact on aquatic plankton variety, density, and accessibility to the fishes. Fish are typically sorted as lean fat when fat is under 5 $\%$ 28. The findings in our present study on a crude fat content range between $6.54 \%$ to $6.45 \%$ which is the moderate value of crude fat content have relevance with other reported data 29-32. It is a general trend that the fat content gradually increases with age and size of the small fishes 32 .

Fats in fishes are significant for energy to save. It fills in as prescient evaluations of fish condition 33-36. As the fat substance increases, the water content falls and the other way around. The present study showed that the whole of fat and moisture for any of the studied fishes approximates $80 \%$ which has a close resemblance with other researchers in this field 37-39. Prior investigation archived that the fat substance of the investigated fish ran from 1.54 to $6.28 \%$ which has pertinence to our findings 40. Water is crucial for the transportation of food substances like fat, protein, etc. to the cells, organs, and different parts of the fish for proper co-ordination. Body fluids move nutrients, metabolites, etc. and water is the main component in these fluids. Water is bonded to the proteins and in the free form which has welldefined biological roles 41 . In our study ash content of the studied fish ranges between $3.33 \%$ to $3.49 \%$. A larger amount of ash prompts having an extra elevated amount of mineral in bones 42 .

\section{CONCLUSION}

The taste, freshness, size, and other related outside appearances ought not to be the major attraction to be considered in settling on a choice for promoting and utilization of fishes. The outcome acquired in this analysis has given logical data and point by point learning of the proximate analysis of Barilius bendelisis , a significant selling fish of the area of Torsa, Raidak-1, Jaldhaka (Mansai) stream. Further specific detailed studies are required to explore the amino acid profile, fatty acid profile, and mineral quantities to set up a standard nutritional database of small indigenous fishes (SIS) of other rivers of this locality. Some local indigenous fish species have been identified that would significantly add to multiple nutrients intake of public health importance. The outcome of the present study significantly expands 
the current information on the nutritional value of the indigenous fish species available in the Cooch Behar district of West Bengal. Therefore, it can be suggested that small indigenous fish species (SIS) might be a good choice for the people of rural as well as semi-urban area to meet their everyday dietary supplement prerequisites just as combat micronutrient inadequacies in connection to their health benefits.

\section{ACKNOWLEDGEMENTS}

The authors acknowledge the Head, Department of Chemistry, Cooch Behar Panchanan University, Cooch Behar-736101 and Principal, Tufanganj Mahavidyalaya, Cooch Behar-736160 for providing necessary laboratory facilities for carrying out the research work.

Conflict of interest: The authors declare that they have no actual and potential conflict of interest.

\section{REFERENCES}

A. Mahanty, S. Ganguly, A. Verma, S. Sahoo, S. Mitra, P. Paria, P. Sharma, A.P. Singh, B.P. Mohanty. Nutrient profile of small indigenous fish Puntius sophore: proximate composition, amino acid, fatty acid and micronutrient profiles. National AcademyScience Letters. Vol. 37 No. 1, pp. 39-44, 2014.

A. Salam , M. Ali , AM. Chatta, QU. Zuman. Growth performance of cultured exotic silver carp (Hypophthalmicthys molitrix) under semi-intensive farming: and Ecological Approach. Acta Sc. Vol. 3, pp. 89-100, 1993.

A. A. Oladimeji, S. 0. E Sadiku. Mineral constituents of Lates niloticus (L) Synodontis schall (Broch and Schneider) and Sarotherodon galilaeus (Trewaves) from Zaria (Nigeria) Dam. Journal of Animal Production and Research. Vol. 11, pp. 45-52, 1991.

A. E. Andrew. Fish Processing Technology. University of IIorin press, Nigeria, pp. 7-8, 2001.

AH. Weatherly, HS. Gill. The Biology of Fish Growth. Academic Press, London. UK., 1987.

A0. Adeqoye Ayinla, T. Idoruboye-Obu, V. Langholz HT, Omuanme, V. Vehlow . Fatty acid composition of the developmental stages of some mesha in relation to temperature and ration size. J Fish Res Board Can. Vol. 26, pp.2364-2394, 2003.

AOAC. Official Methods of Analysis, 18th ed. Association of official Analytical Chemists, Washington, DC., USA. 18. 2005

ARE. Sinclair, P. Duncan. Indices of the condition in tropical ruminants, East Africa wild J. Vol. 10, pp. 143-149, 1972.

B. P. Mohanty, M. S. Yengkokpam and S. Ganguly, S. Fish fauna of Manipur and optimal utilization to meet the food and nutritional security of the region, Souvenir: Nutritional interface meet on "Innovative Approaches for Development of Freshwater Aquaculture in Manipur'(under MEH programme of ICAR-CIFA),
2018.

C. Debnath, L. Sahoo, A. Singha, G. S. Yadav, M. Datta and S. V. Ngachan. Protein and mineral compositions of some local fishes of tripura, India. Indian Journal of Hill Farming,Vol. 27 No. 1, pp. 210-218, 2014.

D. Sharma, M. S. Akhtar, P. Das, P. Gadiya, G. Shahi, $\mathrm{N}$ and A. Ciji. Proximate and mineral composition of some selected coldwater fishes of upland Himalaya, Nutrition \&t Food Science. Vol. 44 No. 6, pp. 554-561, 2014.

Dean LK. Nutrition and Preparation. In R. E. Martin, G.J. Flick eds, The Seafood Industry Published Van Nostrand Rainhold, New York. Published Van Nostrand Rainhold, New York, pp. 255-267, 1990.

Declaration of Helsinki. Amended by World Medical Assembly, Venice, Italy, 1964 and 1983. BMJ. 1996. Vol. 3 No. 70, pp. 1448

E M. V. Uboma, NO. Fadayomoi, Ladipo 00, VO. Sagua. Fish production plan for Nigeria. Natural Committee on Green Revolution, Study Report of Fisheries, 1981.

FA0. The state of world fisheries and aquaculture, Rome: Food and agricultural organization of the United Nations, 2010.

FA0. The state of world fisheries and aquaculture, Rome: Food and agricultural organization of the United Nations. 2015.

FA0. The State of World Fisheries and Aquaculture. FA0 Fisheries and Aquaculture Department. FAO, Rome, pp. 18, 2014..

Gunstone FD. An Introduction to the Chemistry and Biochemistry of fatty acids and their glycerides. Chapman and Hold Ltd. U.K. Vol. 25 No. 26, 1969.

ID. Iles, RJ. Wood. The Fat/Water Relationship in North Sea Herring, Clupea Harengus and its possible significance. J Marine Boil Assoc. Vol. 45, pp. 353-366, 1965.

J. Murray , JR. Burt. The Composition of Fish. Torry Advis. Note 38 Torry Research Station, Aberdeen, 1969.

J. Murray , JR, Burt. The Composition of Fish. Torry Advis.Note 38 Torry Research Station, Aberdeen, 1969.

J. Murray , JR. Burt . The Composition of Fish. Torry Advis. Note 38 Torry Research Station, Aberdeen, 1969.

J. Z. Han, Y. B. Wang. Proteomics: present and future in food science and technology, Trends in Food Science and Technology. Vol. 19 No. 1, pp. 26-30, 1998.

JR. Brett, JE. Shelbousne, CT. Shoop. Growth rate and body composition of fingerling Socheye Salmon Oncorhynchus mesha in relation to temperature and ration size. J. Fish Res. Board Can. Vol.26, pp. 23642394, 1969.

K.C. Jayaram. Catfishes of India. Narendra Pub. House. New Delhi, India, 2006.

K.C. Jayaram. The Freshwater Fishes of Indian Region. Narendra Pub. House. New Delhi, 1999. 
Kor. Quality and Quantity Changes in Fresh fish-4. Chemical composition. FAO fish Utilization and Marketing Services. Viale delle, 00100. Rome Italy.1995. http://www.fao.org/docep/v7180e05.htm.viwed on 14.12.2018

Love RM. The Chemical Biology of fishes. Academic press 1 London, UK. 1970.

M. A. Azim, M. R. Islam, M. B. Hossain and M. H. Minar. Seasonal variations in the proximate composition of Gangetic Sillago, Sillaginopsis panijus (Perciformes: Sillaginidae). Middle-East Journal of Scientific Research. Vol.11 No. 5, pp. 559-562, 2012.

M. A. Hossain, K. Afsana, A. K. M. Azad Shah, A. K. M.. Nutritional value of some small indigenous fish species (SIS) of Bangladesh. Bangladesh Journal of Fisheries Research. Vol. 3 No. 1, pp77-85, 1999.

M. A. Hossain, K. Afsana, K, A. K. M. Azad Shah. Nutritional value of some small indigenous fish species (SIS) of Bangladesh. Bangladesh Journal of Fisheries Research. Vol. 3, No. 1, pp. 77-85, 1999.

M. N. Hossain, H. Afroz, M. Z. Haque and M. Begum. Evaluation of nutritional properties of some small indigenous fishes species in Bangladesh. International Journal of Biosciences, Vol.6 No. 6, pp 102-109, 2015. M. S. A. Mazumder, M. M. Rahman, M. M, A.T.A. Ahmed, M. Begum and M. A. Hossain. Proximate composition of some small indigenous fish species (SIS) in Bangladesh. International Journal of sustainable crop production. Vol. 3 No. 4, pp. 18-23, 2008.

N. Roos, M. A. Wahab, C. Chamnan and S.H. Thilsted. The role of fish in food-based strategies to combat vitamin $\mathrm{A}$ and mineral deficiencies in developing countries. The Journal of Nutrition. Vol. 137 No. 4, pp. 1106-1109,2007.
NH . Poulter, L. Nicolaides. Studies of the iced storage characteristics and composition of a variety of Bolivian freshwater fish. I. Altiplano fish. J Food Technol. Vol. 20, pp. 437-449, 1985.

0. Anthony, J. Richard, A. Lucky. Biochemical composition of five fish species (C. laticeps; D. rostratus; S. schall; S. mystus and $\mathrm{H}$. bebe) from river Niger in Edo State, Nigeria. International Journal of Fisheries and Aquatic Studies. Vol. 4 No. 3, pp. 507-512, 2016. P. K. Talwar, A.G. Jhingran. Inland Fishes of India and Adjacent Countrie. New Delhi, India: Oxford and I.B.H. Publishing Company Ltd. Vol. 1 and 2, 1991.

R. A. Felts, F. Rajts and M. Akhteruzzaman. Small indigenous fish species culture in Bangladesh (Technical Brief), IF ADEP sub-project-2. Development of inland fisheries. Vol. 41. 1996.

S. Ahmed, Rahman, A. F. M. A. Mustafa, M. G., Hossain, M. B. and N. Nahar. Nutrient composition of indigenous and exotic fishes of rainfed waterlogged paddy fields in Lakshmipur, Bangladesh. World Journal of Zoology. Vol. 7 No. 2, pp. 135-140, 2012.

Stansby. Proximate Composition of fish. In: E. Heen and R. Kreuzer (ed) Fish in nutrition, fishing News Books Ltd., London, pp. 55-60. 1962

T. V. Sankar. and A. Ramachandran. Changes in biochemical composition in Indian major carps in relation to size. Fishery Technology. Vol. 38, pp. 22-27, 2001

W. Lakra, S. Sarkar, U. K. A. Gopalakrishnan, A. Kathirvelpandian. Threatened freshwater fishes of India. National Bureau of Fish Genetic Resources, 2010.

W.E. Connor, M. Neuringer, S. Reisbick. Essential fatty acids: the importance of n-3 fatty acids in the retina and brain. Nutr. Rev. Vol. 5, No. 4, pp. 21-29, 1991. 